\title{
Eutrophication and overfishing in temperate nearshore pelagic food webs: a network perspective
}

\author{
Vera Vasas ${ }^{1,4, *}$, Christiane Lancelot ${ }^{1}$, Véronique Rousseau ${ }^{1}$, Ferenc Jordán ${ }^{2,3}$ \\ ${ }^{1}$ Ecologie des Systèmes Aquatiques, Université Libre de Bruxelles, Campus Plaine CP 221, Boulevard du Triomphe, \\ 1050 Bruxelles, Belgium \\ ${ }^{2}$ Collegium Budapest, Institute for Advanced Study, Szentháromság u. 2, 1014 Budapest, Hungary \\ ${ }^{3}$ Animal Ecology Research Group, Hungarian Academy of Sciences, Hungarian Natural History Museum, Ludovika t. 2, \\ 1083 Budapest, Hungary
}

${ }^{4}$ Present address: Department of Plant Taxonomy and Ecology, Eötvös Loránd University, Pázmány Péter s. 1/C, 1117 Budapest, Hungary

\begin{abstract}
We investigated the effects of human activities on the pelagic food web structure of nearshore marine ecosystems. Their generic structure was established on the basis of literature review and analyzed by qualitative structural network analysis. Two main issues were addressed: (1) the role of species capable of forming harmful algal blooms (HABs) and red tides (Noctiluca spp.), as well as the role of jellyfish, in eutrophicated systems; (2) the contribution of human influences on food webs, focusing on bottom-up (increased nutrient loading) and top-down (overfishing) effects. Results suggest that HAB-forming species and Noctiluca stimulate the microbial network, but reduce higher trophic levels such as commercially important fish species. Jellyfish act as a buffer in eutrophicated and overfished systems, as they retain nutrients from the water column, but their blooms lead to a massive accumulation of large phytoplankton organisms. Anthropogenic nutrient enrichment favors undesirable species because of their specific position in the food web, and this crucial position may explain their far-reaching effects. Finally, while it appears that overfishing of piscivorous fishes inhibited HABs and supported blooms of diatoms and other large algae in the past, the present-day loss of planktivorous fishes acts synergistically with nutrient enrichment in promoting $\mathrm{HAB}$ species, Noctiluca and jellyfish. These fundamental constraints, which are inherent in the generic structure of pelagic food webs, thus largely determine community dynamics in marine coastal ecosystems.
\end{abstract}

KEY WORDS: Food web · Eutrophication - Overfishing · Network analysis · Coastal ecosystem · Indirect effects · Harmful algal blooms · Gelatinous plankton

Resale or republication not permitted without written consent of the publisher

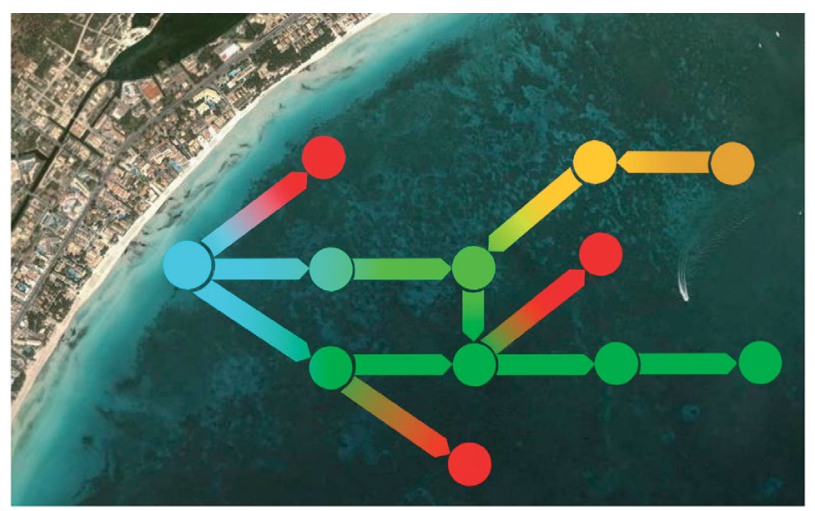

Eutrophication and overfishing are threatening marine coastal communities worldwide. Visible consequences are harmful algal blooms and jellyfish outbreaks. The analysis of the pelagic food web structure by Vasas et al. (diagrammatically idealized above) helps us to understand the mechanisms by which eutrophication and overfishing can generate ecosystem shifts. Illustration: Sándor Snepp; background from Google Earth ${ }^{T M}$

\section{INTRODUCTION}

Coastal waters receive large amounts of anthropogenic nutrients from domestic and industrial effluents and agricultural runoff. Effects of coastal eutrophication are discernible at all trophic levels (Cloern 2001) and appear as direct and indirect qualitative changes in pelagic food webs, e.g. proliferation of harmful algal blooms (HABs), extinction of species at higher trophic levels, and reduced yields of harvestable fishes and invertebrates. These alterations of the food web struc- 
ture are primarily caused by an excessive input of anthropogenic nutrients having altered N:P:Si ratios (excess of $\mathrm{N}$ and $\mathrm{P}$ ) in comparison with natural aquatic systems (Billen et al. 1991).

High-biomass blooms of harmful species at different trophic levels are one response of the coastal system to nutrient enrichment. In temperate coastal waters, 3 groups with different trophic positions are considered as harmful and as indicators of eutrophication: photosynthetic algae that form HABs (Glibert \& Pitcher 2001), the red-tide ichthyotoxic dinoflagellate Noctiluca spp. (Okaichi \& Nishio 1976, Daskalov 2002), and jellyfish (e.g. Arai 2001); the jellyfish are considered dead ends in the food web. Autotrophic and heterotrophic HAB species are separated in the analysis, because they occupy different trophic levels.

Recent field studies (Daskalov 2002, Gucu 2002, Lancelot et al. 2002) and theoretical evidence (Jordán \& Wyatt 2006) show links between HABs, jellyfish blooms and overfishing, confirming the observation that multiple stressors operate in natural communities (Cloern 2001). The existence of trophic cascades, i.e. of far-reaching top-down effects of predators in aquatic ecosystems, imply that fisheries actively modify the ecosystem, rather than being merely beneficiaries of sea resources (Pace et al. 1999).

The worldwide problems of increased nutrient loading and overfishing call for generic and holistic approaches to assess their combined effect, and structural analysis of trophic networks is a useful tool for investigating their causes and consequences. Relationships between parts and the whole can be investigated from a network perspective (Higashi \& Burns 1991); in this study, we studied changes at the level of the whole system that are due to isolated modification of its components. To identify principal mechanisms underlying the global degradation of coastal ecosystems, we analyzed the topological structure of a generic pelagic food web. In this approach, only the very primary information of 'who eats whom' is considered, hence giving information about the basic organization of the system. Such simple models are not able to describe the dynamical behavior of a given system, but they give information about the core functions determining its behavior (e.g. Vasas \& Jordán 2006).

The present model can be applied to all temperate coastal water ecosystems with only minor local modifications. Special attention was given to highlighting the most typical relationships between nutrients and organisms, and to understanding the role and position of harmful eutrophication-indicator species in the network. To achieve this objective, we quantified the role of the 3 selected harmful groups (inedible blooming algae, Noctiluca spp., jellyfish) according to their positions in the food web, and we explored the extent to which human perturbations (nutrient loading from the bottom up, and overfishing from the top down) might influence their blooms. This analysis discriminates between inedible HAB-forming and other algae, because the method only allows the separation of groups on the basis of trophic position; we note, however, that many innocuous species also bloom, and that edible HAB species may exist.

\section{METHODS}

Network construction. Trophic groups specific to the generic pelagic food web and the relationships between them were identified based on literature review (references in Table 1). Trophic groups were defined on the basis of their trophic functions in the ecosystem. They represent both tropho-species, i.e. groups of species that have the same set of predators and prey, and nutrient pools. A tropho-species may be either a taxonomically homogeneous or a distant group of species (Turner \& Roff 1993). In some cases different life stages or toxic/non-toxic forms of the same species may belong to different tropho-species.

A trophic relationship between 2 tropho-species was only considered if it represents an important preypredator interaction. The importance of the interaction and the contribution of each trophic group to different nutrient pools were based on a literature survey (Table 1) and field data (Rousseau et al. 2000). The food web model is thus qualitative, as it is based on the existence of the main relationships, rather than on actual diet or flow information.

Structural network analysis. We used a slightly modified version of the mixed trophic impacts method (Ulanowicz \& Puccia 1990, Vasas \& Jordán 2006), which calculates direct and indirect trophic interactions from trophic flow data. In the original method, the dietary coefficient $\left(g_{i j}\right)$ is the effect of prey $i$ on predator $j$ and represents the actual proportion of $i$ within the diet of $j$. For this network analysis we only considered the presence/absence of prey-predator interactions (e.g. Fig. 1, where $i=\mathrm{A}, \mathrm{B}, \mathrm{C}$ ), and we assume that each prey has the same effect on a given predator; thus

$$
g_{i j}=1 / D_{j, \text { in }}
$$

where $D_{j, \text { in }}$ is the number of prey tropho-species of $j$ (called indegree). Similarly, the negative effect of predator $i$ (Fig. 1, where $i=\mathrm{D}, \mathrm{E}$ ) on its prey $j\left(f_{i j}\right)$ is measured by the fraction of net output consumed by predator $i$ :

$$
f_{i j}=1 / D_{j, \text { out }}
$$

where $D_{j, \text { out }}$ (called outdegree) is the number of predators of $j$ and non-predatory mortality factors (stress-induced lysis or sedimentation). Net output had 
Table 1. Tropho-species: code, size, input and output of matter. Recent reviews are cited where possible. LDOM: labile dissolved organic matter; SDOM: semi-labile DOM; POM: particulate organic matter

\begin{tabular}{|c|c|c|c|c|c|}
\hline Code & Trophic group & Size $(\mu \mathrm{m})$ & Input & Output & Source ${ }^{a}$ \\
\hline PicoPI & $\begin{array}{l}\text { Pico- } \\
\text { phytoplankton }\end{array}$ & $<2$ & $\mathrm{NH} 4, \mathrm{NO} 3, \mathrm{PO} 4$ & $\begin{array}{l}\text { Grazed by HetNanoFI } \\
\text { Release of LDOM }\end{array}$ & $\begin{array}{l}19,21 \\
15\end{array}$ \\
\hline AutNanoFI & $\begin{array}{l}\text { Autotrophic } \\
\text { nanoplankton }\end{array}$ & 2 to 20 & $\mathrm{NH} 4, \mathrm{NO} 3, \mathrm{PO} 4$ & $\begin{array}{l}\text { Grazed by } \mu Z \text { ZooPI } \\
\text { Release of LDOM }\end{array}$ & $\begin{array}{l}19,22 \\
15\end{array}$ \\
\hline LAutFI & $\begin{array}{l}\text { Large autotrophic } \\
\text { flagellates }\end{array}$ & 20 to 200 & $\mathrm{NH} 4, \mathrm{NO} 3, \mathrm{PO} 4$ & $\begin{array}{l}\text { Grazed by MesoZooPI } \\
\text { Release of LDOM }\end{array}$ & $\begin{array}{l}9,11 \\
15\end{array}$ \\
\hline Diat & Diatoms & $\begin{array}{l}2 \text { to } \\
2000\end{array}$ & $\mathrm{NH} 4, \mathrm{NO} 3, \mathrm{PO} 4, \mathrm{Si}$ & $\begin{array}{l}\text { Grazed by MesoZooPI } \\
\text { Grazed by Noctiluca } \\
\text { Infected by VirDiat } \\
\text { Release of LDOM, SDOM } \\
\text { Release of POM } \\
\text { Sedimentation }\end{array}$ & $\begin{array}{l}9,17 \\
3,12 \\
7 \\
15,17 \\
17 \\
17,24\end{array}$ \\
\hline InedAlg & $\begin{array}{l}\text { Inedible bloom- } \\
\text { forming algae }\end{array}$ & $\begin{array}{l}5 \text { to } \\
2000\end{array}$ & $\mathrm{NH} 4, \mathrm{NO} 3, \mathrm{PO} 4$ & $\begin{array}{l}\text { Infected by VirlnedAlg } \\
\text { Release of LDOM, SDOM } \\
\text { Release of POM } \\
\text { Sedimentation }\end{array}$ & $\begin{array}{l}7,4 \\
15,18 \\
18 \\
18,24\end{array}$ \\
\hline FreeBac & $\begin{array}{l}\text { Free-living } \\
\text { bacteria }\end{array}$ & $<2$ & $\begin{array}{l}\text { LDOM } \\
\text { SDOM }\end{array}$ & $\begin{array}{l}\text { Ingested by HetNanoFI } \\
\text { Infected by VirBac } \\
\text { Release of NH4, PO4 }\end{array}$ & $\begin{array}{l}19,21 \\
7,8 \\
13\end{array}$ \\
\hline POM-Bac & $\begin{array}{l}\text { POM-attached } \\
\text { bacteria }\end{array}$ & $<2$ & POM & $\begin{array}{l}\text { Ingested by HetNanoFI } \\
\text { Liberation of SDOM } \\
\text { Release of NH4, PO4 } \\
\text { Sedimentation }\end{array}$ & $\begin{array}{l}19,21 \\
1,20 \\
13 \\
24\end{array}$ \\
\hline HetNanoFI & $\begin{array}{l}\text { Heterotrophic } \\
\text { nanoflagellates }\end{array}$ & 2 to 20 & $\begin{array}{l}\text { PicoPI } \\
\text { FreeBac } \\
\text { POM-Bac }\end{array}$ & $\begin{array}{l}\text { Ingested by } \mu \mathrm{ZOOPI} \\
\text { Release of LDOM, SDOM } \\
\text { Release of POM } \\
\text { Release of NH4, PO4 }\end{array}$ & $\begin{array}{l}19 \\
15,19 \\
19,24 \\
5,19\end{array}$ \\
\hline$\mu Z o o P I$ & $\begin{array}{l}\text { Micro- } \\
\text { zooplankton }\end{array}$ & 20 to 200 & $\begin{array}{l}\text { AutNanoFI } \\
\text { HetNanoFI }\end{array}$ & $\begin{array}{l}\text { Preyed by MesoZooPI } \\
\text { Release of LDOM, SDOM } \\
\text { Release of POM } \\
\text { Release of NH4, PO4 }\end{array}$ & $\begin{array}{l}19 \\
15,19,23 \\
19,24 \\
5,19\end{array}$ \\
\hline MesoZooPI & $\begin{array}{l}\text { Meso- } \\
\text { zooplankton }\end{array}$ & $\begin{array}{l}200 \text { to } \\
2000\end{array}$ & $\begin{array}{l}\text { LAutFI } \\
\text { Diat } \\
\mu \text { ZooPl }\end{array}$ & $\begin{array}{l}\text { Preyed by Jellyfish, PlvFish } \\
\text { Release of LDOM, SDOM } \\
\text { Release of POM } \\
\text { Release of NH4, PO4 }\end{array}$ & $\begin{array}{l}10,16 \\
15,23 \\
24 \\
6\end{array}$ \\
\hline Noctiluca & Noctiluca spp. & $\begin{array}{l}200 \text { to } \\
2000\end{array}$ & $\begin{array}{l}\text { Diat } \\
\text { POM }\end{array}$ & $\begin{array}{l}\text { Infected by VirNoc } \\
\text { Release of LDOM, SDOM } \\
\text { Release of NH4, PO4 } \\
\text { Sedimentation }\end{array}$ & $\begin{array}{l}2 \\
15 \\
14 \\
24\end{array}$ \\
\hline Jellyfish & Jellyfish & $>2000$ & MesoZooPI & Contribution to sedimentation & 24 \\
\hline PlvFish & $\begin{array}{l}\text { Planktivorous } \\
\text { fishes }\end{array}$ & $>2000$ & MesoZooPI & $\begin{array}{l}\text { Preyed by PiscFish } \\
\text { Contribution to sedimentation }\end{array}$ & $\begin{array}{l}10 \\
24\end{array}$ \\
\hline BentFish & $\begin{array}{l}\text { Benthic-feeding } \\
\text { fishes }\end{array}$ & $>2000$ & $\begin{array}{l}\text { None (feeds outside } \\
\text { of pelagic food web) }\end{array}$ & $\begin{array}{l}\text { Preyed by PiscFish } \\
\text { Contribution to sedimentation }\end{array}$ & $\begin{array}{l}10 \\
24\end{array}$ \\
\hline PiscFish & Piscivorous fishes & $>2000$ & PlvFish, BentFish & \multirow{5}{*}{$\begin{array}{l}\text { Contribution to sedimentation } \\
\text { Release of LDOM, SDOM, POM } \\
\text { Release of LDOM, SDOM, POM } \\
\text { Release of LDOM, SDOM, POM } \\
\text { Release of LDOM, SDOM, POM }\end{array}$} & 24 \\
\hline VirDiat & Diat viruses & 0.02 to 0.2 & Diat & & $7,15,25$ \\
\hline VirlnedAlg & InedAlg viruses & 0.02 to 0.2 & InedAlg & & $4,7,15,25$ \\
\hline VirBac & FreeBac viruses & 0.02 to 0.2 & FreeBac & & $7,8,15,25$ \\
\hline VirNoc & Noctiluca viruses & 0.02 to 0.2 & Noctiluca & & $7,15,25$ \\
\hline \multicolumn{2}{|c|}{$\begin{array}{l}\text { aSorted according to output terms } \\
\text { (1) Azam \& Cho (1987) } \\
\text { (2) Beltrami \& Carroll (1994) } \\
\text { (3) Buskey (1995) } \\
\text { (4) Brussard et al. (2004) } \\
\text { (5) Caron \& Goldman (1990) } \\
\text { (6) Frangoulis et al. (2005) } \\
\text { (7) Fuhrman (1999) } \\
\text { (8) Fuhrman (2000) }\end{array}$} & \multicolumn{2}{|c|}{$\begin{array}{l}\text { (9) Harris et al. (2000) } \\
\text { (10) Hart \& Reynolds (2002) } \\
\text { (11) Kiørboe \& Nielsen (1994) } \\
\text { (12) Kiøboe \& Titelman (1998) } \\
\text { (13) Kirchman (2000) } \\
\text { (14) Montani et al. (1998) } \\
\text { (15) Nagata (2000) } \\
\text { (16) Purcell (1997) } \\
\text { (17) Sarthou et al. (2005) }\end{array}$} & \multicolumn{2}{|c|}{$\begin{array}{l}\text { (18) Schoemann et al. (2005) } \\
\text { (19) Sherr \& Sherr (2002) } \\
\text { (20) Smith et al. (1992) } \\
\text { (21) Strom (2000) } \\
\text { (22) Strom (2002) } \\
\text { (23) Strom et al. (1997) } \\
\text { (24) Turner (2002) } \\
\text { (25) Wilhelm \& Suttle (1999) }\end{array}$} \\
\hline
\end{tabular}




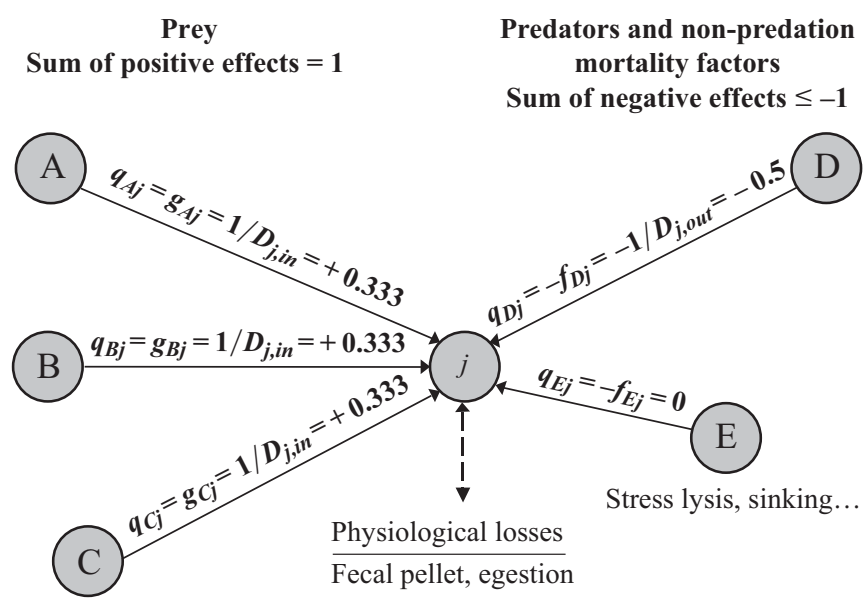

Fig. 1. Calculation of the direct net impact of prey (Group A, B, C) and predator species (Group D, E) on a given species $j$. Positive effects of prey and negative effects of predators depend on the respective number of tropho-species

originally been defined as the total output, excluding respiration. In this application, however, we excluded every release that is related to ecophysiological processes in healthy organisms (leakage, fecal pellet production, egestion), since we focused on interactions, rather than on energetics. The mass fluxes of non-predation mortality factors were considered with regard to the receiving component (the different organic and inorganic nutrient pools), but they have no effect on the source component; thus $f_{i j}=0$. These processes are called donor-controlled.

The net impact $(q)$ of $i$ upon $j$ is $q_{i j}=\left(g_{i j}-f_{i j}\right)$ and is defined as the one-step (direct) effect of $i$ on $j$ (Fig. 1). Its values range from -1 to +1 . Taking every pair of $\mathrm{N}$ nodes, we calculated the above defined direct net impacts and constituted the $\mathrm{N} \times \mathrm{N}$ net impact matrix, [Q], where the entry in the $i$ th row and the $j$ th column represents the net impact of $i$ upon $j$. Assuming that the direct impacts are additive and multiplicative, the total (direct and indirect) effects, called mixed trophic impact $\left(m_{i j}\right.$ entries of matrix $\left.[\mathbf{M}]\right)$, are calculated by summarizing all integer powers of [Q], using the following equation derived from the input-output theory applied to energy flows in ecosystems by Hannon (1973):

$$
[\mathbf{M}]=\{[\mathbf{I}]-[\mathbf{Q}]\}^{-1}-[\mathbf{I}]
$$

where [I] is the identity matrix.

The computation of overall pairwise interactions gives a general overview of ecosystem functioning. Nutrients evidently support all components in a food web, but our analysis concerned the share of each component. Trophic cascades originating from predators result in alternating abundance (or biomass) patterns between the various trophic levels, e.g. an abundant top predator in a 3-level food chain results in lower abundances of mid-level consumers and higher abundance of basal producers (Pace et al. 1999). From this structural analysis, one may assess indirect effects such as the propagation of positive effects of nutrients or trophic cascades.

Topological keystones. Species are not equally important in maintaining the integrity of ecosystems, and the heterogeneous nature of trophic interactions is a fundamental feature of natural communities (Margalef 1991). Species that have a large impact on the ecosystem, disproportional to their (possibly) small biomass, are considered to be keystone species (Power et al. 1996). One of the very few quantitative approaches for their identification is based on their position in food webs. The bottom-up component of the keystone index ( $K_{b i}$ Jordán et al. 1999) was used to quantify the role of each species in order to explore possible relationships between the most important and the harmful groups in a community. The keystone index $(K)$ modified from the net status index (Harary 1961), allows the estimation of the number of species that would be seriously affected after a large perturbation (or extinction) of a given species. The bottom-up component of keystone index $K_{b, i}$ is defined as:

$$
K_{b, i}=\sum_{j=1}^{n} \frac{1}{d_{j}}\left(1+K_{b, j}\right)
$$

where $n$ is the number of predators consuming species $i$, and $d_{j}$ is the number of prey species of its $j$ th predator. $K_{b, j}$ is the bottom-up keystone index of the $j$ th predator, which means that the formula is recursive; its calculation should, therefore, start with the top predators (Fig. 2). This index satisfies our interest in propagating bottom-up (nutrient loading) effects in the food web, because it emphasizes vertical over horizontal interactions and enables us to identify the bottom-up $\left(K_{b, i}\right)$ keystone position of a species.

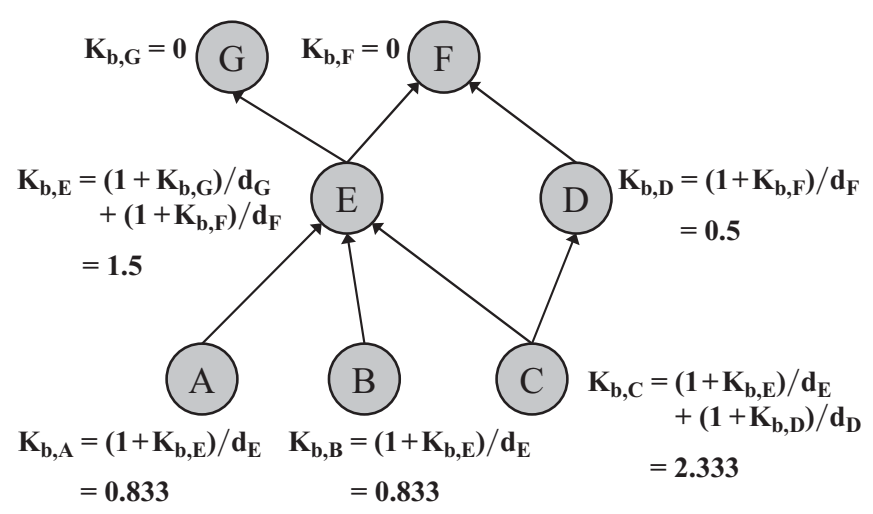

Fig. 2. Calculation of the bottom-up keystone index (Jordán et al. 1999). The index is zero for top predators (Group G, F) by definition, and subsequently calculated for their prey (see Table 3) 


\section{RESULTS AND DISCUSSION}

\section{Structure of the generic food web}

Based on our literature review, 26 'trophic' groups19 tropho-species and 7 nutrient pools-were identified as relevant in temperate coastal ecosystems (Fig. 3, Table 1). The basic definition of tropho-species was based on their metabolism (autotrophic, heterotrophic) and size, since these are the main determinants of their trophic roles. This classification was expanded, as organisms of similar size may differ in prey selection or trophic fate.

We defined 5 phytoplankton groups, based on their bottom-up and top-down characteristics (Fig. 3). These are picoplankton PicoPI (e.g. Synechococcus spp., Prochlorococcus spp., picoeukaryotes), autotrophic flagellates AutNanFI (nano-sized phytoplankton belonging to haptophytes, chrysophytes, cryptophytes, prasinophytes), large autotrophic flagellates LAutFI (e.g. non-toxic dinoflagellates Ceratium spp.), diatoms Diat, and inedible blooming ( $\mathrm{HAB})$ algae InedAlg. The latter was defined on the basis of the 'loophole' hypothesis (Bakun \& Broad 2003), i.e. blooming species are defined as those capable of escaping predation controls by zooplankton because of their size, shape or toxicity (Irigoien et al. 2005). InedAlg thus include algae forming high biomass blooms (e.g. Phaeocystis globosa colonies) and toxic species (haptophytes, e.g. Prymnesium parvum, Chrysochromulina polylepis; raphidophytes, e.g. Heterosigma akashiwo; dinoflagellates, e.g. Alexandrium spp., Karenia brevis; cyanobacteria, e.g. Nodularia spumigena). Phytoplankton, on the other hand, may remain ungrazed if zooplankton is heavily controlled by predators (Daskalov 2002). The harmful effects of InedAlg and ungrazed edible phytoplankton will be discussed separately (see 'Structural analysis: Consequences of human impacts').

The microbial network (Fig. 3) rests on the bacterial utilization of organic matter in the water column and the consumption of small auto- and heterotrophic groups, generally one order of magnitude smaller than themselves (Sheldon et al. 1972). Free-living bacteria FreeBac utilize dissolved organic matter (DOM), while

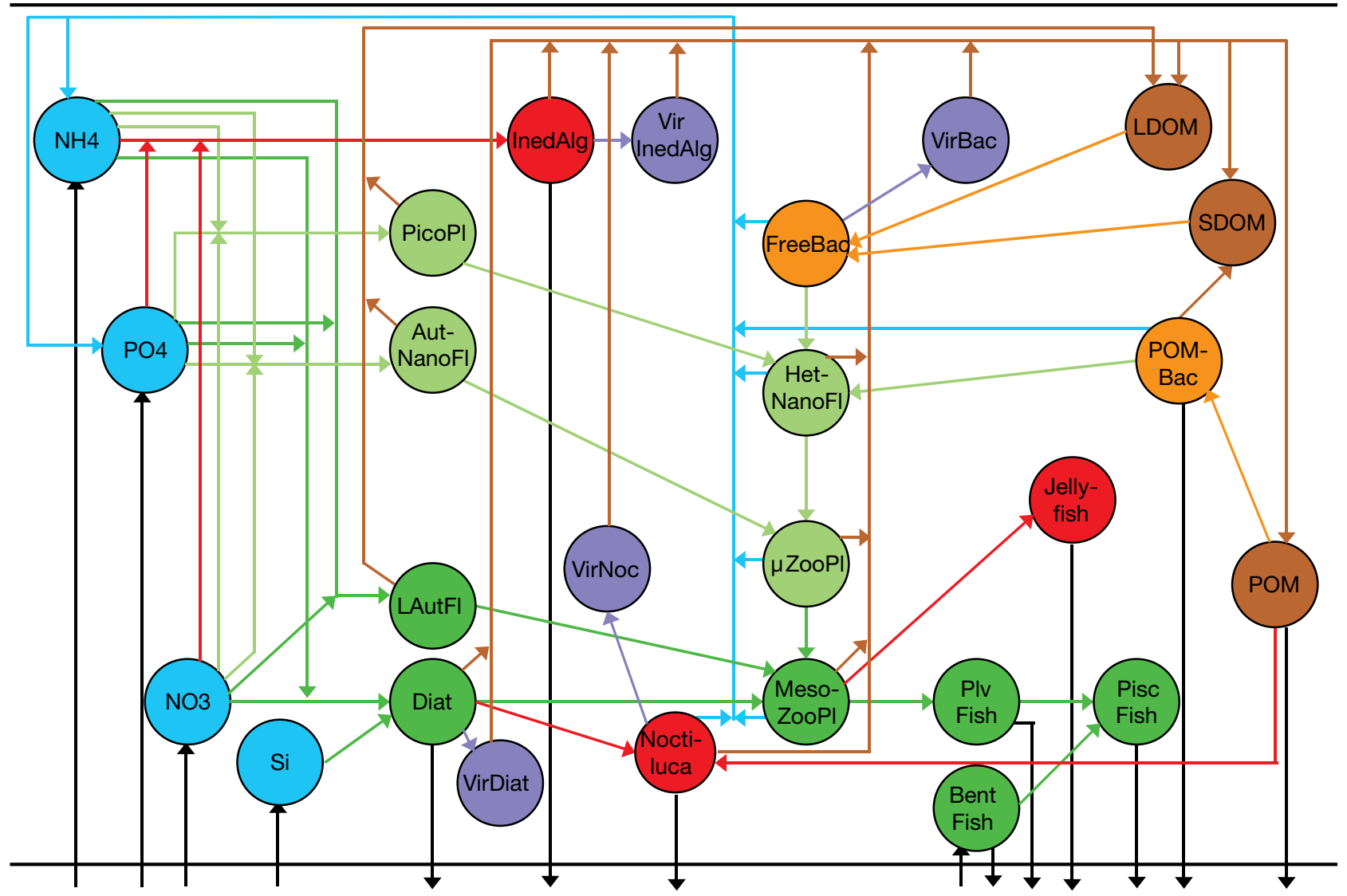

Fig. 3. Generic structure of the pelagic food web. Circles represent trophic groups and arrows represent mass transfers between trophic groups. Acronyms defined in Table 1. Red: harmful groups; purple: viruses; dark green: linear food chain; light green and light brown: microbial food web (light brown: bacteria); blue: inorganic nutrients; brown: organic nutrients; black: exchange with the sediment. Arrows have the same color as the recipient group 
bacteria attached to detrital particles POM-Bac hydrolyze particulate organic matter POM and release DOM into the surrounding water. Both bacterial groups, along with picoplankton, support the growth of heterotrophic nanoflagellates HetNanoFI, which are in turn consumed by microzooplankton $\mu$ ZooPI (ciliates, dinoflagellates, copepod nauplii and copepodits I-II), together with AutNanFI (Fig. 3).

The higher trophic levels include mesozooplankton MesoZooPI (mainly copepods and copepodits III \& IV) that graze on large phytoplankton (LAutFI and Diat) and $\mu$ ZooPI (Fig. 3). In eutrophicated coastal waters, MesoZooPI may be outnumbered by the omnivorous dinoflagellate Noctiluca that forms red-tide (occasionally green-tide) blooms, which significantly influence the functioning of the ecosystem (e.g. Yilmaz et al. 2005). When blooming, Noctiluca is toxic to fish because of its release of ammonium (Okaichi \& Nishio 1976). The unsaturated feeding function determined for Noctiluca when growing under laboratory conditions with different prey (E. Breton pers. comm.), suggests that Noctiluca has a great potential to benefit from an increased phytoplankton biomass in eutrophicated waters. Accordingly, Noctiluca has been reported as an important indicator of anthropogenic influence (Daskalov 2003).

The food requirements of top predators, like piscivorous fish species PiscFish, are fulfilled by planktivorous PlvFish and benthic-feeding BentFish fish. PlvFish compete for MesoZooPI with Jellyfish (members of the Cnidaria and Ctenophora), the third harmful trophic group (Fig. 3). Jellyfish are undesirable for humans, since they compete with PlvFish and, being a trophic dead end, they do not transfer energy and nutrients towards the top predators.

At the base of the food web, viruses are responsible for much of the bacterial mortality and the decay of phytoplankton blooms; their role in nutrient regeneration is thus far from negligible (Thingstad et al. 1993). In this study we consider 4 host-specific groups of viruses susceptible of infesting Diat, InedAlg, FreeBac and Noctiluca. Diat and InedAlg were chosen on the basis of their ability to form huge transient blooms. Viruses infesting attached bacteria were not considered due to the generally low number of their hosts (Azam et al. 1983, Becquevort et al. 1998). Despite a lack of literature evidence, Noctiluca-specific viruses were included in this study because of the observed high density and sudden collapse of Noctiluca blooms that might indicate a viral attack (Beltrami \& Carroll 1994).

The generic food web included 7 nutrient pools (Fig. 3). All 4 inorganic nutrient pools (ammonium NH4, nitrate NO3, phosphate $\mathrm{PO} 4$ and silicic acid $\mathrm{Si}$ ), which support phytoplankton growth, exchange with the sediment, and NH4 and PO4 are remineralized by hetero- trophic components of the food web (FreeBac, POMBac, HetNanoFI, $\mu$ ZooPI, MesoZooPI, Noctiluca). Larger heterotrophic organisms (Jellyfish, PlvFish, BentFish and PiscFish) remineralize nutrients only to a negligible extent, because of their relatively low biomass (Schneider 1990, Hudson et al. 1999).

The detrital organic matter is composed of dissolved (DOM) and particulate POM forms. Two pools of DOM are distinguished on the basis of their biodegradability: labile LDOM and semi-labile SDOM (Fig. 3). Direct excretion by all phytoplankton groups flows to LDOM and is easily accessible for FreeBac. Other processes, namely overflow during nutrient limitation from phytoplankton, stress lysis or viral lysis, egestion, sloppy feeding and fecal pellet production, contributes to all 3 organic pools (LDOM, SDOM, POM).

The structure of this generic pelagic food web of temperate coastal ecosystems is basically the same in different ecosystems, but the dominance of trophic groups or pathways changes in line with environmental conditions.

\section{Structural analysis}

Role of harmful species

The trophic role of the 3 harmful species (InedAlg, Noctiluca, Jellyfish) was determined on the basis of pairwise interactions between the components of the generic food web (Table 2).

InedAlg (Fig. 4a) has a strong negative effect on all phytoplankton groups, due to competition for inorganic nutrients. On the other hand, InedAlg positively influences the lower food web (FreeBac, POM-Bac, HetNanoFl) through the release of organic matter after viral and stress lysis, but unlike other large-sized phytoplankters (LAutFI, Diat), it negatively affects the higher food web (MesoZooPl, PlvFish, PiscFish; Fig. 4a). This result is supported by the low trophic efficiency estimated for a Phaeocystis-dominated food web in the North Sea, and explained by the important flow of primary products throughout the bacterial loop (Rousseau et al. 2000).

The role of Noctiluca in the web is ambiguous (Fig. 4b). It impacts MesoZooPI negatively, but 1 order of magnitude less than InedAlg (Fig. 4a,b); Noctiluca and MesoZooPI compete, however, for the same prey (Diat). Thus, we expect that any increase in Noctiluca biomass exerts a slightly negative effect on MesoZooPI and-as a consequence-on fishes. This result can possibly be explained with the intensive and short nutrient cycles at the very basis of the food web, in which Noctiluca is involved. The direct nutrient catabolic release associated to Noctiluca growth, and the 
Table 2. Pairwise interactions between components of the generic food web, quantified as mixed trophic impacts $\left(m_{i j}\right.$ values). See Table 1 for abbreviations

\begin{tabular}{|c|c|c|c|c|c|c|c|c|c|c|c|c|c|}
\hline From & PicoPI & $\begin{array}{c}\text { Aut } \\
\text { NanoFI }\end{array}$ & LAutFI & Diat & InedAlg & $\begin{array}{l}\text { Free } \\
\text { Bac }\end{array}$ & POM-Bac & $\begin{array}{c}\text { Het } \\
\text { NanoFI }\end{array}$ & $\mu \mathrm{ZooPI}$ & $\begin{array}{l}\text { Meso } \\
\text { ZooPI }\end{array}$ & Noctiluca & $\begin{array}{l}\text { Jelly } \\
\text { fish }\end{array}$ & PlvFish \\
\hline PicoPI & -0.2570 & -0.1208 & -0.0689 & -0.0393 & -0.0608 & -0.0292 & -0.0672 & 0.1758 & 0.0397 & -0.0122 & -0.0070 & -0.0122 & -0.0091 \\
\hline AutNanoFI & 0.0818 & -0.3272 & -0.1070 & -0.0460 & -0.0693 & 0.0402 & 0.0594 & -0.1743 & 0.2347 & 0.0145 & -0.0276 & 0.0145 & 0.0109 \\
\hline LAutFI & -0.1388 & -0.0058 & -0.2130 & -0.0641 & -0.0762 & -0.0079 & -0.0288 & 0.0373 & -0.0958 & 0.1115 & -0.0278 & 0.1115 & 0.0836 \\
\hline Diat & -0.0899 & 0.0118 & -0.1180 & -0.3770 & -0.0276 & 0.0495 & 0.0532 & 0.0530 & -0.0487 & 0.0811 & 0.2635 & 0.0811 & 0.0608 \\
\hline InedAlg & -0.0930 & -0.0674 & -0.0557 & -0.0388 & -0.3052 & 0.0413 & 0.0915 & 0.0194 & -0.0061 & -0.0179 & 0.0234 & -0.0179 & -0.0134 \\
\hline FreeBac & -0.0438 & 0.0106 & 0.0309 & 0.0178 & 0.0344 & -0.5940 & 0.0123 & 0.0896 & 0.0352 & 0.0149 & 0.0281 & 0.0149 & 0.0112 \\
\hline POM-Bac & -0.0829 & 0.0135 & 0.0459 & 0.0414 & 0.0538 & -0.0077 & -0.2707 & 0.1547 & 0.0582 & 0.0259 & -0.0570 & 0.0259 & 0.0194 \\
\hline HetNanoFI & -0.4504 & -0.0711 & 0.0698 & 0.0475 & 0.0942 & -0.0856 & -0.1461 & -0.4240 & 0.1967 & 0.0558 & 0.0710 & 0.0558 & 0.0419 \\
\hline HZooPI & 0.3773 & -0.4601 & -0.0296 & 0.0182 & 0.0458 & 0.0817 & 0.1559 & -0.3162 & -0.4788 & 0.0906 & 0.0060 & 0.0906 & 0.0680 \\
\hline MesoZooPI & -0.0959 & 0.2740 & -0.3625 & -0.0268 & 0.0482 & -0.0215 & -0.0310 & 0.1602 & -0.2097 & -0.5732 & 0.0084 & 0.4268 & 0.3201 \\
\hline Noctiluca & 0.0512 & 0.0315 & 0.0480 & -0.0718 & 0.0348 & 0.0479 & -0.0691 & -0.0049 & 0.0149 & -0.0016 & -0.3038 & -0.0016 & -0.0012 \\
\hline Jellyfish & 0.0480 & -0.1370 & 0.1813 & 0.0134 & -0.0241 & 0.0107 & 0.0155 & -0.0801 & 0.1049 & -0.2134 & -0.0042 & -0.2134 & -0.1601 \\
\hline PlvFish & 0.0360 & -0.1028 & 0.1359 & 0.0100 & -0.0181 & 0.0081 & 0.0116 & -0.0601 & 0.0786 & -0.1601 & -0.0031 & -0.1601 & -0.3701 \\
\hline BentFish & -0.0120 & 0.0343 & -0.0453 & -0.0033 & 0.0060 & -0.0027 & -0.0039 & 0.0200 & -0.0262 & 0.0534 & 0.0010 & 0.0534 & -0.2100 \\
\hline PiscFish & -0.0240 & 0.0685 & -0.0906 & -0.0067 & 0.0121 & -0.0054 & -0.0078 & 0.0401 & -0.0524 & 0.1067 & 0.0021 & 0.1067 & -0.4200 \\
\hline VirDiat & 0.0086 & 0.0014 & 0.0332 & -0.1226 & 0.0155 & 0.0258 & 0.0599 & 0.0121 & 0.0193 & -0.0125 & -0.0212 & -0.0125 & -0.0094 \\
\hline VirlnedAlg & 0.0216 & 0.0263 & 0.0281 & 0.0150 & -0.2216 & 0.0219 & 0.0400 & 0.0163 & 0.0116 & 0.0097 & 0.0237 & 0.0097 & 0.0073 \\
\hline VirBac & 0.0125 & -0.0015 & -0.0059 & -0.0068 & -0.0072 & -0.1673 & 0.0643 & -0.0221 & -0.0081 & -0.0037 & 0.0174 & -0.0037 & -0.0028 \\
\hline VirNoc & -0.0265 & -0.0067 & -0.0064 & 0.0260 & -0.0016 & 0.0197 & 0.0936 & 0.0244 & 0.0046 & 0.0043 & -0.2006 & 0.0043 & 0.0032 \\
\hline LDOM & -0.0219 & 0.0053 & 0.0155 & 0.0089 & 0.0172 & 0.2030 & 0.0062 & 0.0448 & 0.0176 & 0.0075 & 0.0140 & 0.0075 & 0.0056 \\
\hline SDOM & -0.0219 & 0.0053 & 0.0155 & 0.0089 & 0.0172 & 0.2030 & 0.0062 & 0.0448 & 0.0176 & 0.0075 & 0.0140 & 0.0075 & 0.0056 \\
\hline POM & -0.0573 & 0.0292 & 0.0698 & 0.0055 & 0.0712 & 0.0162 & 0.6947 & 0.1522 & 0.0657 & 0.0251 & 0.2911 & 0.0251 & 0.0188 \\
\hline $\mathrm{NH} 4$ & 0.1752 & 0.1626 & 0.1556 & 0.0930 & 0.1559 & 0.0272 & 0.0316 & 0.0327 & 0.0453 & 0.0523 & 0.0529 & 0.0523 & 0.0392 \\
\hline PO4 & 0.1752 & 0.1626 & 0.1556 & 0.0930 & 0.1559 & 0.0272 & 0.0316 & 0.0327 & 0.0453 & 0.0523 & 0.0529 & 0.0523 & 0.0392 \\
\hline NO3 & 0.1752 & 0.1626 & 0.1556 & 0.0930 & 0.1559 & 0.0272 & 0.0316 & 0.0327 & 0.0453 & 0.0523 & 0.0529 & 0.0523 & 0.0392 \\
\hline $\mathrm{Si}$ & -0.0225 & 0.0030 & -0.0295 & 0.1558 & -0.0069 & 0.0124 & 0.0133 & 0.0133 & -0.0122 & 0.0203 & 0.0659 & 0.0203 & 0.0152 \\
\hline From & BentFish & PiscFish & VirDiat & $\begin{array}{c}\text { Vir } \\
\text { InedAlg }\end{array}$ & VirBac & VirNoc & LDOM & SDOM & POM & $\mathrm{NH} 4$ & $\mathrm{PO} 4$ & $\mathrm{NO} 3$ & $\mathrm{Si}$ \\
\hline PicoPl & 0.0030 & -0.0030 & -0.0393 & -0.0608 & -0.0292 & -0.0070 & 0.0687 & 0.0195 & 0.0207 & -0.0764 & -0.0764 & -0.0906 & 0.0393 \\
\hline AutNanoFI & -0.0036 & 0.0036 & -0.0460 & -0.0693 & 0.0402 & -0.0276 & -0.0035 & -0.0503 & -0.0277 & -0.0855 & -0.0855 & -0.1065 & 0.0460 \\
\hline LAutFI & -0.0279 & 0.0279 & -0.0641 & -0.0762 & -0.0079 & -0.0278 & 0.0349 & -0.0212 & -0.0102 & -0.1021 & -0.1021 & -0.1004 & 0.0641 \\
\hline Diat & -0.0203 & 0.0203 & 0.6230 & -0.0276 & 0.0495 & 0.2635 & 0.0779 & 0.1237 & 0.0797 & -0.0154 & -0.0154 & -0.0799 & -0.6230 \\
\hline InedAlg & 0.0045 & -0.0045 & -0.0388 & 0.6948 & 0.0413 & 0.0234 & 0.0494 & 0.0939 & 0.1012 & -0.0663 & -0.0663 & -0.0880 & 0.0388 \\
\hline FreeBac & -0.0037 & 0.0037 & 0.0178 & 0.0344 & 0.4060 & 0.0281 & -0.3518 & -0.3406 & 0.0571 & 0.0738 & 0.0738 & -0.0100 & -0.0178 \\
\hline POM-Bac & -0.0065 & 0.0065 & 0.0414 & 0.0538 & -0.0077 & -0.0570 & 0.0295 & 0.1020 & -0.1934 & 0.1147 & 0.1147 & -0.0143 & -0.0414 \\
\hline HetNanoFI & -0.0140 & 0.0140 & 0.0475 & 0.0942 & -0.0856 & 0.0710 & 0.1407 & 0.1785 & 0.1419 & 0.1574 & 0.1574 & 0.0620 & -0.0475 \\
\hline$\mu Z \circ o$ PI & -0.0227 & 0.0227 & 0.0182 & 0.0458 & 0.0817 & 0.0060 & -0.0506 & -0.0205 & -0.0022 & 0.0867 & 0.0867 & 0.0097 & -0.0182 \\
\hline MesoZooPI & -0.1067 & 0.1067 & -0.0268 & 0.0482 & -0.0215 & 0.0084 & 0.0393 & 0.0565 & 0.0491 & 0.0802 & 0.0802 & 0.0326 & 0.0268 \\
\hline Noctiluca & 0.0004 & -0.0004 & -0.0718 & 0.0348 & 0.0479 & 0.6962 & 0.0679 & 0.0708 & -0.0716 & 0.0789 & 0.0789 & -0.0187 & 0.0718 \\
\hline Jellyfish & 0.0534 & -0.0534 & 0.0134 & -0.0241 & 0.0107 & -0.0042 & -0.0196 & -0.0282 & -0.0246 & -0.0401 & -0.0401 & -0.0163 & -0.0134 \\
\hline PlvFish & -0.2100 & 0.2100 & 0.0100 & -0.0181 & 0.0081 & -0.0031 & -0.0147 & -0.0212 & -0.0184 & -0.0301 & -0.0301 & -0.0122 & -0.0100 \\
\hline BentFish & -0.2633 & 0.2633 & -0.0033 & 0.0060 & -0.0027 & 0.0010 & 0.0049 & 0.0071 & 0.0061 & 0.0100 & 0.0100 & 0.0041 & 0.0033 \\
\hline PiscFish & -0.5267 & -0.4733 & -0.0067 & 0.0121 & -0.0054 & 0.0021 & 0.0098 & 0.0141 & 0.0123 & 0.0200 & 0.0200 & 0.0081 & 0.0067 \\
\hline VirDiat & 0.0031 & -0.0031 & -0.1226 & 0.0155 & 0.0258 & -0.0212 & 0.0382 & 0.0513 & 0.0659 & 0.0247 & 0.0247 & 0.0128 & 0.1226 \\
\hline VirlnedAlg & -0.0024 & 0.0024 & 0.0150 & -0.2216 & 0.0219 & 0.0237 & 0.0373 & 0.0448 & 0.0481 & 0.0437 & 0.0437 & 0.0261 & -0.0150 \\
\hline VirBac & 0.0009 & -0.0009 & -0.0068 & -0.0072 & -0.1673 & 0174 & 0.2297 & 0.2464 & 0.0533 & -0.0153 & -0.0153 & 0.0018 & 0.0068 \\
\hline VirNoc & -0.0011 & 0.0011 & 0.0260 & -0.0016 & 0.0197 & -0.2006 & 0.0311 & 0.0525 & 0.1057 & -0.0047 & -0.0047 & 0.0030 & -0.0260 \\
\hline LDOM & -0.0019 & 0.0019 & 0.0089 & 0.0172 & & 0.0140 & -0.1759 & -0.1703 & 0.0286 & 0.0369 & 0.0369 & -0.0050 & -0.0089 \\
\hline SDOM & -0.0019 & 0.0019 & 0.0089 & 0.0172 & 0.2030 & 0.0140 & -0.1759 & -0.1703 & 0.0286 & 0.0369 & 0.0369 & -0.0050 & -0.0089 \\
\hline POM & -0.0063 & 0.0063 & 0.0055 & 0.0712 & 0.0162 & & 0.0635 & 0.1374 & -0.2292 & 0.1542 & 0.1542 & -0.0237 & -0.0055 \\
\hline $\mathrm{NH} 4$ & -0.0131 & 0.0131 & 0.0930 & 0.1559 & 0.0272 & 0.0529 & 0.0693 & 0.0449 & 0.0479 & -0.1139 & -0.1139 & -0.1485 & -0.0930 \\
\hline PO4 & -0.0131 & 0.0131 & 0.0930 & 0.1559 & 0.0272 & 0.0529 & 0.0693 & 0.0449 & 0.0479 & -0.1139 & -0.1139 & -0.1485 & -0.0930 \\
\hline $\mathrm{NO} 3$ & -0.0131 & 0.0131 & 0.0930 & 0.1559 & 0.0272 & & 0.0693 & 0.0449 & 0.0479 & -0.1139 & -0.1139 & -0.1485 & -0.0930 \\
\hline $\mathrm{Si}$ & -0.0051 & 0.0051 & 0.1558 & -0.0069 & 0.0124 & 0.0659 & 0.0195 & 0.0309 & 0.0199 & -0.0038 & -0.0038 & -0.0200 & -0.1558 \\
\hline
\end{tabular}



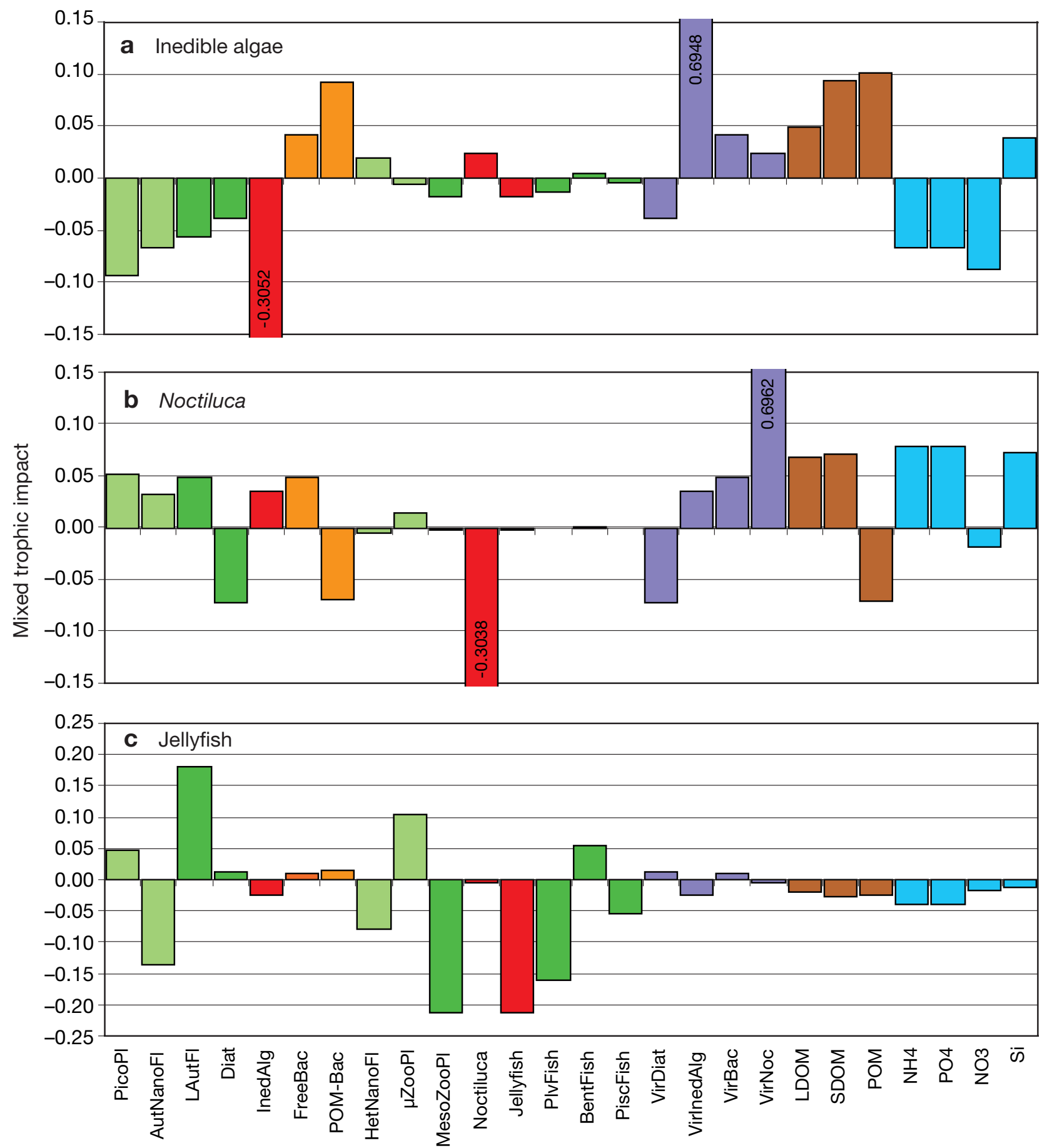

Fig. 4. Mixed trophic impact of harmful tropho-species. Colors explained in Fig. 3; see Table 1 for abbreviations

bacterial mineralization of Noctiluca lysis products, can support diatom growth, but more importantly, other phytoplankton groups as well. Such a promotion of phytoplankton, combined with the stimulation of bacteria, is - through many pathways-beneficial to fishes. These longer pathways may at least partially replace the diatom pathway, which is disrupted by Noctiluca. Hence, nutrient remineralization appears to be the main trophic role of Noctiluca in the food web, as suggested for North Sea blooms by Schoemann et al. (1998).

Jellyfish affect MesoZooPI more negatively than fishes do, and as a consequence, the same applies to the inorganic and organic nutrient pools (Fig. 4c). Jellyfish may thus play a buffer role for nutrients, as recently hypothesized for a coastal lagoon ecosystem 
(Fernández et al. 2005). In addition, Jellyfish are likely to impede InedAlg and Noctiluca, preventing their blooms by taking up and storing nutrients, and disrupting nutrient cycling in the water column. Thus, from a human perspective, Jellyfish could play a beneficial role in eutrophicated and heavily overfished ecosystems. However, Jellyfish are more voracious predators of MesoZooPI than are PlvFish, both because of their feeding characteristics and because they are not controlled by predators (Fig. 4c; cf. Fig. 6a). If Jellyfish outcompete PlvFish, the top-down cascade originating from the upper trophic level is reinforced and leads to a massive accumulation of large phytoplankton biomass (Diat and LAutFI), if nutrient concentrations are high enough (Daskalov 2003). At low nutrient concentrations, the 4-step trophic chain AutNanoFI- $\mu$ ZooPIMesoZooPI-Jellyfish prevails in the system and an increased level of jellyfish predation leads to a decrease in total phytoplankton biomass. In eutrophicated waters, however, large algae and the 3-step chain Diat/LAutFI-MesoZooPI-Jellyfish are of greater importance, and the cascading effects of jellyfish predation on copepods lead to increased total phytoplankton biomass (Stibor et al. 2004). Mass sedimentation of ungrazed phytoplankton biomass may result in hypoxia or anoxia near the bottom (Cloern 2001). These and the strong negative effects on fish and fisheries due to resource competition (see Shiganova 1998 for field evidence from the Black Sea) make jellyfish an undesired group, from a human perspective.

\section{Consequences of human impacts}

Human eutrophication and overfishing affect the food web at several nodes. An increased loading of inorganic (NH4, PO4, NO3) and organic nutrients (LDOM, SDOM, POM) disturbs the food web at the bottom, while fishing pressure modifies top predators (PlvFish, PiscFish). In order to understand how these human impacts may affect the ecosystem, we have analyzed the role these groups play in the food web, with a focus on harmful tropho-species.

Increased nutrient load. Nutrients NH4, PO4 and NO3 are beneficial to all tropho-species except BentFish (since it feeds on prey from outside the pelagic community; Fig. 5a). InedAlg and Jellyfish seem to be favored, compared to Diat and PlvFish (Fig. 5a). This suggests that an increase in inorganic nutrient input will enhance a disproportional biomass development of these undesired species. Noctiluca indirectly benefits from inorganic $\mathrm{N}$ and $\mathrm{P}$ enrichment and, in turn, contributes to this pool with remineralization processes associated with its metabolism. This process is a general feature of heterotrophic tropho-species, including
MesoZooPI. The relative importance of these 2 nutrient cycles may lead to alternative stable states of the ecosystem at high inorganic nutrient levels: one associated with high MesoZooPI, and one with high Noctiluca biomass. The dominance of Noctiluca can be explained by the unexpected result that-even though both groups are direct competitors for Diat-MesoZooPI favors Noctiluca growth through its contribution to POM (Fig. 3), as reported by Kiørboe (2003).

A confusing result is that inorganic $\mathrm{N}$ and $\mathrm{P}$ are increasingly more beneficial to small phytoplankton (Fig. 5a), since every phytoplankton group supports its heterotrophic grazer and the subsequent trophic levels above. Small phytoplankton organisms thus indirectly promote the grazers of their larger competitors. The pattern in our model contradicts the general observation that small phytoplankton is dominant in oligotrophic waters, while eutrophicated waters are dominated by large phytoplankton. This may be an artifact resulting from the simplicity of our model, since dynamical information is lost in structural network analyses. More specifically, the latter cannot account for time lags in the response of predators to changes in prey abundance. Even if the entire prey biomass is consumed in the end, a predator responding with a significant time lag to an increased abundance of prey will allow the prey to develop in a way that mitigates the predator's effects; this feature is not captured by structural network analysis. The observed fact that small predators respond faster to increases in small phytoplankters may counterbalance the advantage that small algae have due to their high competitive abilities for low nutrients (Fogg 1995) and their position in the food web. Further research is needed for understanding this phenomenon.

All harmful groups (InedAlg, Noctiluca, Jellyfish) benefit more from organic nutrient enrichment (LDOM, SDOM, POM) than their respective 'desired' competitor, Diat, MesoZooPI, PlvFish (Fig. 5b,c). Thus, a sustained increase of organic matter may be responsible for the observed disproportional increase in the biomass of the undesired groups. A marked difference between these groups is the role of sink for organic matter played by Jellyfish, while InedAlg and Noctiluca constitute a source of organic matter throughout lysis (Table 1; Fig. 3). As a consequence, InedAlg, Noctiluca and DOM can increase simultaneously and constitute an alternative stable state of the ecosystem.

Consequences of overfishing. Fish-driven trophic cascades may have large effects in ecosystems (Pace et al. 1999), and overfishing largely disturbs the food web (fishing down: Pauly et al. 1998). According to our calculations, PlvFish shows negative effects on Jellyfish and, to a smaller extent, on InedAlg, Noctiluca and all nutrients (Fig. 6a), but it positively affects 

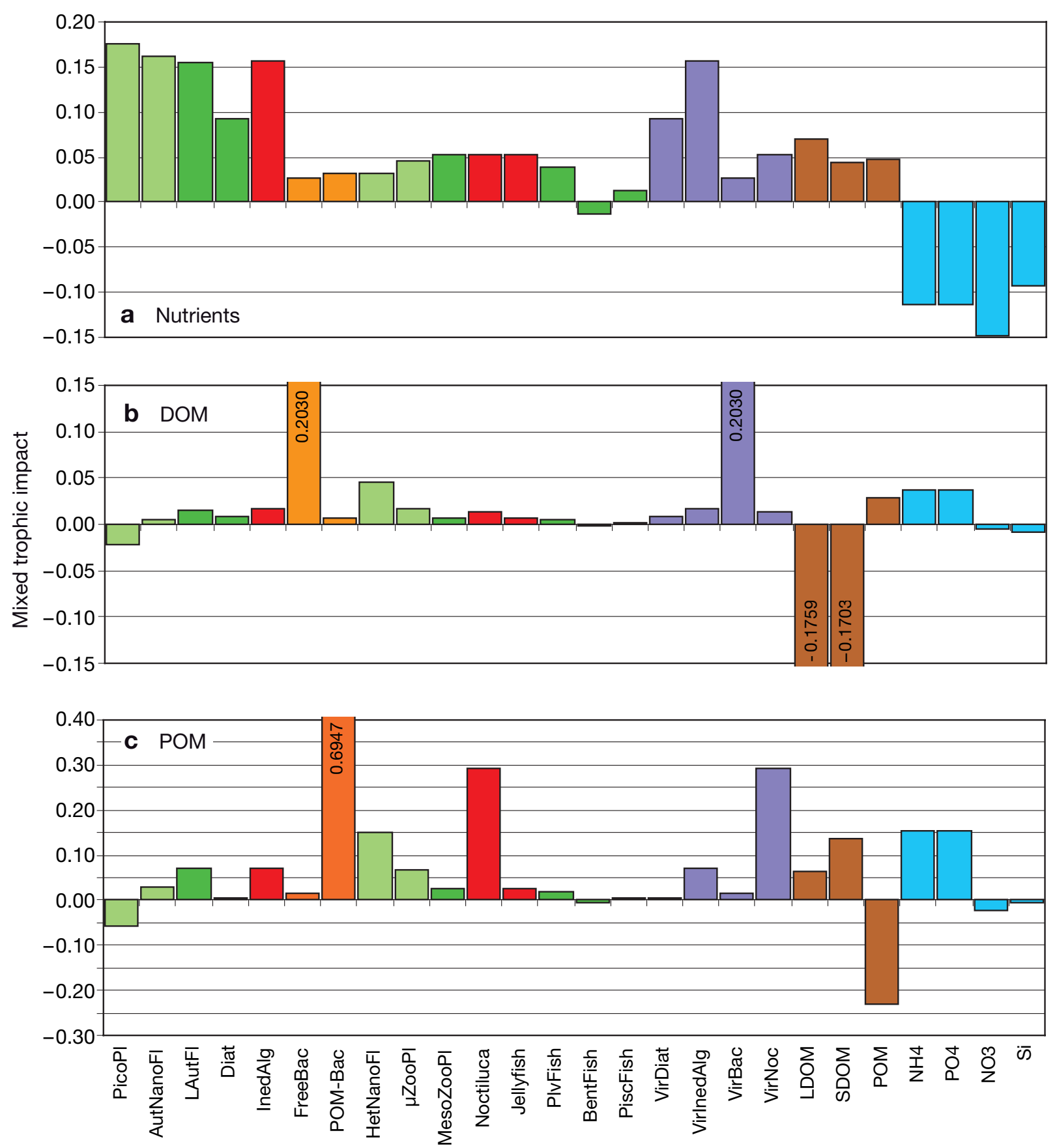

Fig. 5. Mixed trophic impact of inorganic and organic nutrients: (a) $\mathrm{NH}_{4}, \mathrm{PO}_{4}, \mathrm{NO}_{3}$ (b) LDOM, SDOM; (c) POM. Colors explained in Fig. 3; see Table 1 for abbreviations

large phytoplankton (LAutFI and Diat). Therefore, PlvFish overfishing would allow the development of undesired groups (e.g. jellyfish blooms in the Black Sea: Gucu 2002, Lancelot et al. 2002), and increased concentrations of nutrients in the water column. The effects of PIvFish overfishing are, therefore, similar to those subsequent to nutrient enrichment, and synergistically support harmful species, which results in a rapid degradation of the ecosystem. Because of the simplified interactions within the fish community in our model, PiscFish exerts its effects entirely through predation of PlvFish; this group has, thus, opposite effects to PlvFish (Fig. 6b). PiscFish overfishing can lead to blooms of Diat and LAutFI, which remain ungrazed, because the predation pressure of PlvFish tends to suppress MesoZooPI (Daskalov 2002, Jordán 


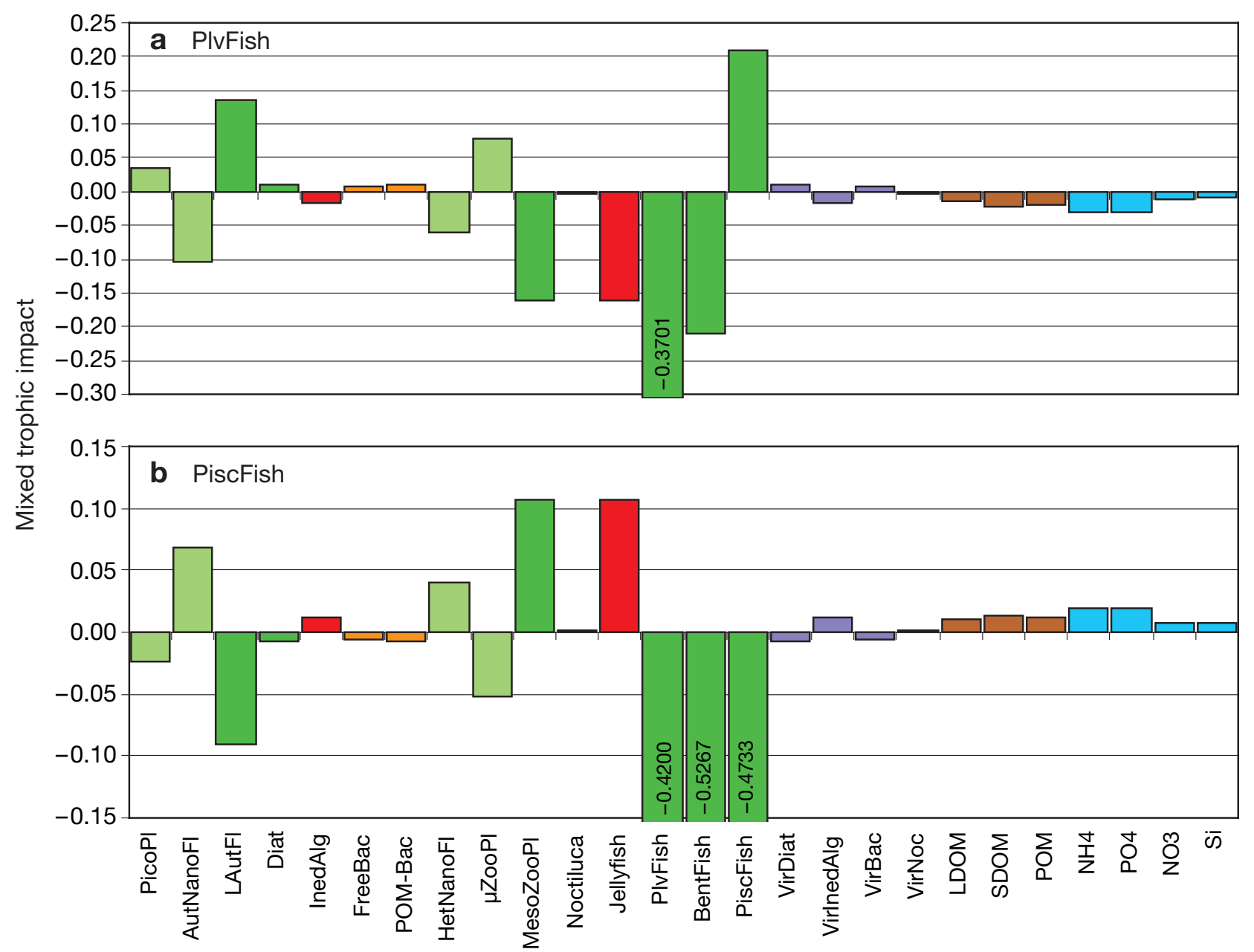

Fig. 6. Mixed trophic impact of fish tropho-species. Colors explained in Fig. 3. See Table 1 for abbreviations

\& Wyatt 2006), similarly to what is described above for jellyfish.

In summary, overfishing of PiscFish (under conditions of nutrient enrichment) may lead to blooms of Diat and LAutFI that remain ungrazed, but overfishing of PlvFish may support harmful species (InedAlg, Noctiluca, Jellyfish). Even in its simplicity, our analysis tentatively explains why the consequences of overfishing in coastal seas were not visible for so long. Historically, overfishing of larger PiscFish was the first step (Pauly et al. 1998), but the subsequent phytoplankton biomass increase seemed to be related to the increase in nutrient loads. However, after depletion of the larger PiscFish, fisheries have turned towards the smaller, but numerous PlvFish (e.g. anchovy). With time, the effects of nutrient enrichment and overfishing started to develop in synergy, resulting in a very visible degradation of the ecosystem, characterized by HABs and jellyfish blooms. One remarkable example is the outburst of Mnemiopsis leidyi in the Black Sea after strong overfishing of anchovy in 1988 (Shiganova 1998).
Positioning of harmful species

The position of harmful species in the food web is far from random, as they disrupt the food web at each basic trophic level: InedAlg increases the primary producers' biomass, Noctiluca that of primary consumers and Jellyfish to biomass of secondary consumers. All these species appear to benefit more from nutrients than their competitors, partly as a result of the absence of predators. The increasing dominance of inedible forms over edible ones in response to nutrient enrichment has been demonstrated both theoretically (e.g. Leibold 1996) and experimentally (e.g. Steiner 2001), but other mechanisms are also involved. Harmful groups are positioned in the network in a way that enables them to exploit the most important bottom-up controllers of the food web (Table 3 ), according to the bottom-up component of the keystone index $\left(K_{b}\right)$. The most important bottom-up controls are reflected by the highest values of $K_{b}$, which gives an approximation of the number of species that would disappear due to 
food shortage after the extinction of the given species. According our calculation of the index of Jordán et al. (1999), the most important groups are: the inorganic nutrients NH3, PO4, NO3 (consumed by InedAlg); Diat and POM (consumed by Noctiluca), and MesoZooPI (consumed by Jellyfish). The crucial position of harmful species in the food web explains their strong undesired effects in ecosystems.

\section{Use of qualitative structural analysis of coastal ecosystems}

Since the literature data required for the establishment of the trophic web was scarce, the results of our structural network analysis are partly speculative. In addition, the qualitative structural approach fails where dynamic features determine the relationships between trophic groups. Nevertheless, the agreement between our model results and the conclusions of elaborate case studies supports the feasibility of the model and underscores the overwhelming importance of the food web structure in community dynamics.

The effects of nutrient loading and overfishing on the 3 harmful tropho-species and their interactions are summarized in Fig. 7. InedAlg blooms support the microbial network and inhibit the transfer of nutrients up the food web, including to commercially important fish species (Fig. 7). The effect of Noctiluca on fishes is less detrimental, since this dinoflagellate is involved in short dynamic nutrient cycles at the base of the food web, and this cycling supports small phytoplankton and bacteria. The developing longer pathway from minute producers to fishes may partially substitute the short chain from diatoms.

In eutrophicated ecosystems, InedAlg and Noctiluca blooms correspond to increased total phytoplankton

Table 3. Bottom-up importance of each trophic group in the generic pelagic food web, calculated as the bottom-up component of the keystone index (Jordán et al. 1999; cf. Fig. 2)

\begin{tabular}{|lc|}
\hline Trophic group & $K_{b}$ \\
\hline NH4, PO4, NO3 & 3.69 \\
Diat & 3.17 \\
POM & 2.69 \\
MesoZooPI & 2.50 \\
FreeBac & 1.69 \\
LDOM, SDOM & 1.35 \\
LAutFI, HZooPI & 1.17 \\
AutNanoFI, HetNanoFI & 1.08 \\
Si & 1.04 \\
InedAlg, Noctiluca & 1.00 \\
PicoPI, POM-Bac & 0.69 \\
PlvFish, BentFish & 0.50 \\
Jellyfish, PiscFish, VirDiat, VirlnedAlg, & 0 \\
VirBac, VirNoc & \\
\hline
\end{tabular}

biomass, supported by positive relationships between elevated chlorophyll a levels, harmful blooms and increased nutrient loading (Cloern 2001, Daskalov 2003). The InedAlg biomass directly contributes to the chlorophyll level, while Noctiluca indirectly supports all non-diatom phytoplankton species (Fig. 4b) with its intensive nutrient regeneration and intensive feeding on Diat. The shift from diatoms to non-siliceous algae in response to eutrophication has been repeatedly pointed out (e.g. Cloern 2001), but the possible contribution of Noctiluca blooms to this shift is new. InedAlg and Noctiluca are fundamentally interrelated in coastal ecosystems, with many mechanisms ensuring the recycling of nutrients in the water column instead of exporting them to fishes.

On the other hand, InedAlg and Noctiluca inhibit Jellyfish blooming (Fig. 7), because they retain nutrients in the water column. Jellyfish is likely to act as a buffer in eutrophicated and overfished systems, since it forms an efficient sink of matter. As a consequence, Jellyfish inhibits InedAlg and Noctiluca as well (Fig. 7). At the same time, Jellyfish blooms lead to a massive biomass accumulation of large phytoplankton because of the reinforced trophic cascade.

Anthropogenic nutrient enrichment favors harmful tropho-species (Fig. 7) more than it benefits desired groups; this has far-reaching effects, because harmful species hold a key position in the food web by exploit-

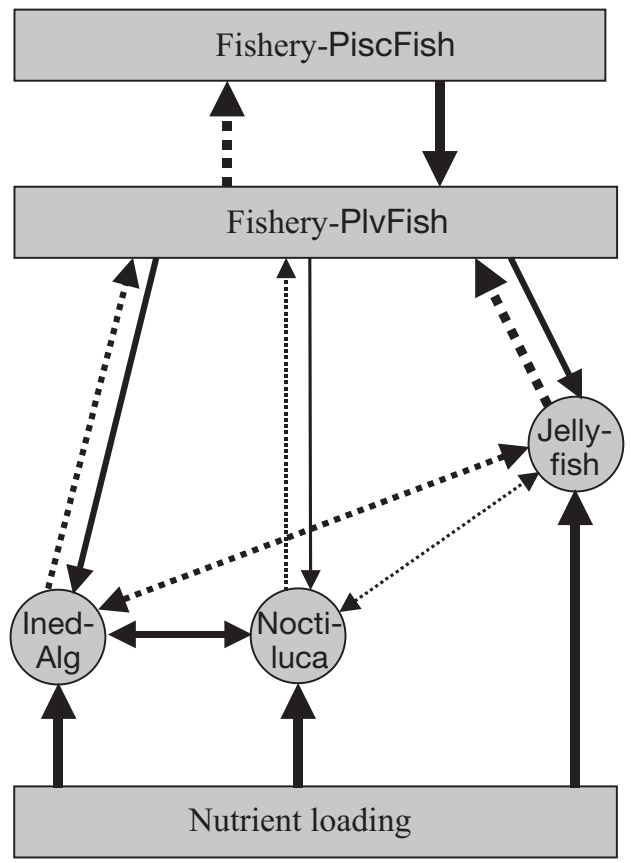

Fig. 7. Diagram of relationships between harmful trophospecies and anthropogenic impacts. Solid arrows: positive effects; dashed arrows: negative effects; double-headed arrows: reciprocal relationship. Width of arrows is proportional to the strength of the calculated trophic impacts 
ing the most important bottom-up controllers. According to our calculations, the trophic level at which overfishing occurs is of crucial importance, as previously suggested by e.g. Pauly et al. (1998). The earlier overfishing of PiscFish appears to sustain blooms of diatoms and other large algae that remain ungrazed, while the present overfishing of PlvFish supports HABspecies and jellies, acting synergistically with nutrient enrichment.

Calculations with modified versions of the web employed in this study (without viruses, without harmful groups, version for the North Sea: V. Vasas et al. unpubl.) indicate that the main conclusions and interaction pathways are robust. Still, we emphasize that the results in this study are not meant as absolute numbers, but rather as characteristic constraints inherent to the structure of the generic food web. The relative importance of these pathways may be quite different, depending on the environmental conditions of the ecosystem, and the next step is a comparison of systems with different structural properties. Moreover, the various roles of nutrients and the effects of unbalanced nutrient enrichment could be examined in the future, based on comparisons of the same web in terms of nitrogen, phosphorus and silica. Major changes to ecosystem state often occur above certain thresholds of stress (Scheffer et al. 2001), and a search for the structural causes behind them is promising. Ecosystems that show threshold behavior are a great challenge to management, and the context described here will serve as a basis to study possible mechanisms of thresholds in pelagic nearshore food webs.

Acknowledgements. The authors thank 3 anonymous referees for constructive comments and suggestions. We are grateful to W.C. Liu for technical help, T. Wyatt for comments on the manuscript, and K. Csepi for linguistic help. This study is a contribution to Stream 3 (Nutrient-driven thresholds of environmental sustainability) of the Integrated Project THRESHOLDS (Thresholds of environmental sustainability), funded by the European Commission (Global Change and Ecosystems) under contract 003933, and to the Belgian federal policy project AMORE III. F.J. was supported by Society in Science: The Branco Weiss Fellowship, ETH Zürich.

\section{LITERATURE CITED}

Arai MN (2001) Pelagic coelenterates and eutrophication: a review. Hydrobiologia 451:69-87

Azam F, Cho BC (1987) Bacterial utilization of organic matter in the sea. In: Fletcher M, Gray TRG, Jones JG (eds) Ecology of microbial communities. Cambridge University Press, Cambridge, p 261-281

Azam F, Fenchel T, Field JG, Gray JS, Meyer-Reil LA, Thingstad F (1983) The ecological role of water-column microbes in the sea. Mar Ecol Prog Ser 10:257-263

Bakun A, Broad K (2003) Environmental 'loopholes' and fish population dynamics: comparative pattern recognition with focus on El Niño effects in the Pacific. Fish Oceanogr 12:458-473

Becquevort S, Rousseau V, Lancelot C (1998) Major and comparable roles for free-living and attached bacteria in the degradation of Phaeocystis-derived organic matter in Belgian coastal waters of the North Sea. Aquat Microb Ecol 14:39-48

Beltrami E, Carroll TO (1994) Modeling the role of viral disease in recurrent phytoplankton blooms. J Math Biol 32: $857-863$

Billen G, Lancelot C, Meybeck M (1991) N, P and Si retention along the aquatic continuum from land to ocean. In: Mantoura RFC, Martin JM, Wollast R (eds) Ocean margin processes in global change, Dahlem Workshop Reports. Wiley, New York, p 19-44

Buskey EJ (1995) Growth and bioluminescence of Noctiluca scintillans on varying algal diets. J Plankton Res 17:29-40

Brussaard CPD (2004) Viral control of phytoplankton populations - a review. J Eukaryot Microbiol 51:125-138

Caron DA, Goldman JC (1990) Protozoan nutrient regeneration. In: Capriulo GM (ed) Ecology of marine protozoa. Oxford University Press, New York, p 283-306

Cloern JE (2001) Our evolving conceptual model of the coastal eutrophication problem. Mar Ecol Prog Ser 210: 223-253

Daskalov GM (2002) Overfishing drives a trophic cascade in the Black Sea. Mar Ecol Prog Ser 225:53-63

Daskalov GM (2003) Long-term changes in fish abundance and environmental indices in the Black Sea. Mar Ecol Prog Ser 255:259-270

Fernández JM, Selma MAE, Aymerich FR, Sáez MTP, Fructuoso MFC (2005) Aquatic birds as bioindicators of trophic changes and ecosystem deterioration in the Mar Menor lagoon (SE Spain). Hydrobiologia 550:221-235

Fogg GE (1995) Some comments on picoplankton and its importance in the pelagic ecosystem. Aquat Microb Ecol 9:33-39

Frangoulis C, Christou ED, Hecq JH (2005) Comparison of marine copepod outfluxes: nature, rate, fate and role in the carbon and nitrogen cycles. Adv Mar Biol 47:253-309

Fuhrman JA (1999) Marine viruses and their biogeochemical and ecological effects. Nature 399:541-548

Fuhrman JA (2000) Impact of viruses on bacterial processes. In: Kirchman DL (ed) Microbial ecology of the oceans. Wiley, New York, p 327-350

Glibert P, Pitcher G (eds) (2001) Global ecology and oceanography of harmful algal blooms. GEOHAB Science Plan, SCOR \& IOC, Baltimore/Paris

Gucu AC (2002) Can overfishing be responsible for the succesful establishment of Mnemiopsis leidyi in the Black Sea? Estuar Coast Shelf Sci 54:439-451

Hannon B (1973) The structure of ecosystems. J Theor Biol 41:535-546

Harary F (1961) Who eats whom? Gen Syst 6:41-44

Harris RP, Irigoien X, Head RN, Rey C and 5 others (2000) Feeding, growth and reproduction in the genus Calanus. ICES J Mar Sci 57:1708-1726

Hart PJB, Reynolds JD (2002) Handbook of fish biology and fisheries. Blackwell, Oxford

Higashi M, Burns TP (eds) (1991) Theoretical studies of ecosystems - the network perspective. Cambridge University Press, Cambridge

Hudson JJ, Taylor WD, Schindler DW (1999) Planktonic nutrient regeneration and cycling efficiency in temperate lakes. Nature 400:659-661

Irigoien X, Flynn KJ, Harris P (2005) Phytoplankton blooms: a 'loophole' in microzooplankton grazing impact? J Plankton Res 27:313-321 
Jordán F, Takács-Sánta A, Molnár I (1999) A reliability theoretical quest for keystones. Oikos 86:453-462

Jordán F, Wyatt T (2006) A graph theory examination of the global spreading hypothesis. Afr J Mar Sci 28:371-374

Kiørboe T (2003) High turnover rates of copepod fecal pellets due to Noctiluca scintillans grazing. Mar Ecol Prog Ser 258:181-188

Kiørboe T, Nielsen TG (1994) Regulation of zooplankton biomass and production in a temperate, coastal ecosystem. 1. Copepods. Limnol Oceonogr 39:493-507

Kiørboe T, Titelman J (1998) Feeding, prey selection and prey encounter mechanisms in the heterotrophic dinoflagellate Noctiluca scintillans. J Plankton Res 20:1615-1636

Kirchman DL (2000) Uptake and regeneration of inorganic nutrients by marine heterotrophic bacteria. In: Kirchman DL (ed) Microbial ecology of the oceans. Wiley, New York, p 261-288

Lancelot C, Staneva J, Van Eeckhout D, Beckers JM, Stanev E (2002) Modelling the Danube-influenced north-western continental shelf of the Black Sea. II. Ecosystem response to changes in nutrient delivery by the Danube River after its damming in 1972. Estuar Coast Shelf Sci 54:473-499

Leibold MA (1996) A graphical model of keystone predators in food webs: trophic regulation of abundance, incidence, and diversity patterns in communities. Am Nat 147:784-812

Margalef R (1991) Networks in ecology. In: Higashi M, Burns TP (eds) Theoretical studies of ecosystems-the network perspective. Cambridge University Press, Cambridge, $\mathrm{p}$ 41-57

Montani S, Pithakpol S, Tada K (1998) Nutrient regeneration in coastal seas by Noctiluca scintillans, a red tide-causing dinoflagellate. J Mar Biotechnol 6:224-228

Nagata T (2000) Production mechanisms of dissolved organic matter. In: Kirchman DL (ed) Microbial ecology of the oceans. Wiley, New York, p 128-160

Okaichi T, Nishio S (1976) Identification of ammonia as the toxic principle of red tide of Noctiluca miliaris. Bull Plankton Soc Japan 23:25-30

Pace ML, Cole JJ, Carpenter SR, Kitchell JF (1999) Trophic cascades revealed in diverse ecosystems. Trends Ecol Evol 14:483-488

Pauly D, Christensen V, Dalsgaard J, Froese R, Torres F Jr (1998) Fishing down marine food webs. Science 279:860-863

Power ME, Tilman D, Estes JA, Menge BA and 6 others (1996) Challenges in the quest for keystones. BioScience 46: 609-620

Purcell JE (1997) Pelagic cnidarians and ctenophores as predators: selective predation, feeding rates and effects on prey populations. Ann Inst Oceanogr Paris 73:125-137

Rousseau V, Becquevort S, Parent JY, Gasparini S, Daro MH, Tackx M, Lancelot C (2000) Trophic efficiency of the planktonic food web in a coastal ecosystem dominated by Phaeocystis colonies. J Sea Res 43:357-372

Sarthou G, Timmermans KR, Blain S, Tréguer P (2005) Growth physiology and fate of diatoms in the ocean: a review. J Sea Res 53:25-42

Scheffer M, Carpenter S, Foley JA, Folke C, Walker B (2001) Catastrophic shifts in ecosystems. Nature 413:591-596

Schneider G (1990) A comparison of carbon based ammonia excretion rates between gelatinous and non-gelatinous

Editorial responsibility: Otto Kinne (Editor-in-Chief), Oldendorf/Luhe, Germany zooplankton: implications and consequences. Mar Biol 106:219 - 225

Schoemann V, de Baar HJW, de Jong JTM, Lancelot C (1998) Effects of phytoplankton blooms on the cycling of manganese and iron in coastal waters. Limnol Oceanogr 43: $1427-1441$

Schoemann V, Becquevort S, Stefels J, Rousseau V, Lancelot C (2005) Phaeocystis blooms in the global ocean and their controlling mechanisms: a review. J Sea Res 53:43-66

Sheldon RW, Prakash A, Sutcliffe Jr WH (1972) The size distribution of particles in the ocean. Limnol Oceanogr $17: 327-340$

Sherr EB, Sherr BF (2002) Significance of predation by protists in aquatic microbial food webs. Antonie Leeuwenhoek 81:293-308

Shiganova TA (1998) Invasion of the Black Sea by the ctenophore Mnemiopsis leidyi and recent changes in pelagic community structure. Fish Oceanogr 7:305-310

Smith DC, Simon M, Alldredge AL, Azam F (1992) Intense hydrolytic enzyme activity on marine aggregates and implications for rapid particle dissolution. Nature 359: 139-142

Steiner CF (2001) The effects of prey heterogeneity and consumer identity on the limitation of trophic-level biomass. Ecology 82:2495-2506

Stibor H, Vadstein O, Diehl S, Gelzleichter A and 10 others (2004) Copepods act as a switch between alternative trophic cascades in marine pelagic food webs. Ecol Lett $7: 321-328$

Strom SL (2000) Bacterivory: interactions between bacteria and their grazers. In: Kirchman DL (ed) Microbial ecology of the oceans. Wiley, New York, p 351-386

Strom SL (2002) Novel interactions between phytoplankton and microzooplankton: their influence on the coupling between growth and grazing rates in the sea. Hydrobiologia 480:41-54

Strom SL, Benner R, Ziegler S, Dagg MJ (1997) Planktonic grazers are a potentially important source of marine dissolved organic carbon. Limnol Oceanogr 42:1364-1374

Thingstad TF, Heldal M, Bratbak G, Dundas I (1993) Are viruses important partners in pelagic food webs? Trends Ecol Evol 8:209-213

Turner JT (2002) Zooplankton fecal pellets, marine snow and sinking phytoplankton blooms. Aquat Microb Ecol 27: $57-102$

Turner JT, Roff JC (1993) Trophic levels and tropho-species in marine plankton: lessons from the microbial food web. Aquat Ecol 7:225-248

Ulanowicz RE, Puccia CJ (1990) Mixed trophic impacts in ecosystems. Coenoses 5:7-16

Vasas V, Jordán F (2006) Topological keystone species in ecological interaction networks: considering link quality and non-trophic effects. Ecol Model 196:365-378

Wilhelm SW, Suttle CA (1999) Viruses and nutrient cycles in the sea. BioScience 49:781-788

Yllmaz IN, Okus E, Yüksek A (2005) Evidences for influence of a heterotrophic dinoflagellate (Noctiluca scintillans) on zooplankton community structure in a highly stratified basin. Estuar Coast Shelf Sci 64:475-485

Submitted: July 21, 2006; Accepted: March 13, 2007

Proofs received from author(s): April 18, 2007 